\title{
Why Timars? Why Now? Ottoman Timars in the Light of Recent Historiography
}

\author{
Douglas A. Howard \\ Calvin College (Grand Rapids, Michigan, USA) \\ dhoward@calvin.edu
}

\begin{abstract}
Ottoman historians lost interest in timars a generation ago due to simultaneous intellectual and political crises, namely methodological skepticism and the end of the cold war. The archival methodology used in timar research was subjected to withering critique, and the underlying motivation for the research, land reform in East-Central Europe and Turkey, was dissipated. Renewed scholarly interest in the timar institution is driven by awareness of transnational themes, efforts to theorize complexity, and the value of transparency and self-consciousness in research agendas.
\end{abstract}

\section{Keywords}

timar - historiography - Eurocentrism - feudalism - cold war - narrative - complexity

Within the space of a couple of months in 2013, two colleagues contacted me about the current state of research on the Ottoman timar institution. One was Linda Darling (University of Arizona), who sent me a draft of a paper she had written analyzing evidence from Ottoman summary timar registers of the sixteenth and seventeenth centuries. The other was Géza Dávid (Eötvös Loránd University of Budapest), who suggested we collaborate to finish my now decades-long project on Ayn Ali's Kavanin-i Al-i Osman (Regulations of the Ottoman Dynasty), the most important Ottoman literary work on timars. With Linda's and Géza's help we called on a few others and organized a panel of papers for the 21st meeting of the CIÉPO, in Budapest in October 2014, two 
of which are presented here. ${ }^{1}$ My initial reaction, however, when I heard from these two colleagues was, "Why timars, and why now?" I still feel a need to explain this.

I wrote my doctoral dissertation on timars in $1987,{ }^{2}$ based mainly on the then little-used ruznamçe daybook registers (a new collection of which had just been catalogued in the Prime Ministry Archives in Istanbul), on Ayn Ali's work, and on various compilations of official sultanic decrees (i.e., kanunnames) about timars. At the time, my work could build upon a strong foundation of available published research. This research continued as several important articles on the timar institution appeared in the late 1980 s and early 199os, and I was able to add a translation and study of one compilation of kanuns about timars. ${ }^{3}$ In the 20 years since, however, it seemed that virtually everyone in the field of Ottoman history lost interest in timars, including me. Thus did I find myself challenged by my two colleagues' recently revived curiosity. I do not claim to have a complete answer to my questions, "Why timars? Why now?" But in the pages that follow, I will offer an explanation of why research in timars declined more than 20 years ago and why we got interested in timars in the first place, and venture some suggestions for future research. My explanations will double as an introduction to the papers presented here.

\section{Defterology and the Grand Narratives}

It seems to me that the loss of interest in timars a generation ago resulted from a confluence of intellectual and political streams whose separate headwaters deserve full exploration. Within Ottoman studies a debate sprang up from a paper Heath Lowry presented at the Fourth International Congress on Ottoman Social and Economic History, in Munich in $1986 .{ }^{4}$ This debate took

1 One of the other papers was by Nil Tekgül, but, due to the constraints of her doctoral program at Bilkent University, it could not be included. It has now been published: Tekgül, Nil, "Cash loans to Ottoman timariots during military campaigns (sixteenth-seventeenth century): a vulnerable fiscal system?" Journal of the Social and Economic History of the Orient, 59 (2016), 590-617.

2 Howard, Douglas A., "The Ottoman Timar System and its Transformation, 1563-1656", Ph.D. Dissertation, Indiana University, 1987.

3 Howard, Douglas A., "Ottoman administration and the timar system: Sûret-i Kânûnnâme-i 'Osmânî Berây-ı Tîmâr Dâden”, Journal of Turkish Studies, 20 (1996), 46-125.

4 Lowry, Heath, "The Ottoman Tahrir Defterleri as a source for social and economic history: pitfalls and limitations", in Studies in Defterology, ed. Heath Lowry and Nejat Göyünç (Istanbul, Isis, 1992). 
place in the years of military domination in Turkey after the 1980 coup, and was overrun later by the cutting of the Iron Curtain, the breakup of the Soviet Union, and the end of the Cold War. The issues raised in Heath's paper and these contemporary political events joined to form one raging methodological current cascading down against state-centered writing of Ottoman history, which effectively submerged timar research for a generation.

Heath Lowry's paper analyzed "pitfalls and limitations" of the research on Ottoman demographic, social, and institutional history that had been based on imperial registry records since the 1930s. Right after World War II ended, a huge collection of registers in the Prime Ministry archives in Istanbul had become available for research. These were the records of the Ottoman imperial registry (the defter-i hakani), including the registers (defters) both detailed (mufassal) and summary (icmal) of the periodic Ottoman cadastral surveys (the tahrirs) from the mid-fifteenth to the late sixteenth centuries. The scholarly world had been aware of these registers. A Hungarian scholar had published a mufassal register in $1886 .{ }^{5}$ Sergei S. Dzhikiia, a Georgian who was a student of M. Fuat Köprülü, published the Georgian survey of 1595, the first volume of which appeared in Tiflis in $1941 .^{6}$ And the existence of the Turkish archival collection was known, as Jean Deny had announced it in his entry on "Timar" in the Encyclopaedia of Islam, which had appeared in $1934 .{ }^{7}$ Lajos Fekete, the Hungarian archivist who had worked in Istanbul to organize the archives there, published the register of Estergom in $1943,{ }^{8}$ and probably was involved in the decision of the Turkish Historical Society to assemble an international team of scholars to publish them. Among this team were Tibor Halasi-Kun, Robert Anhegger, Halil İnalcık, Tayyib Gökbilgin, Şinasi Altundağ, and Ömer Lütfi Barkan. ${ }^{9}$

5 Velics, Antal, “A budai mirmirséghez tartozó nógrádi szandzsák részletes adó-deftere", in Antal Velics and Ernő Kammerer, Magyarországi török kincstári defterek. I. 1543-1635 [Turkish Treasury Defters in Hungary. I. 1543-1635] (Budapest: Athanaeum, 1886), pp. 266-322. I am grateful to Géza Dávid for this and the following reference.

6 Dzhikiia, Sergei Defter-i Mufassal-i Liva-i Gürcistan, 3 vols. (Tiflis: Gūrcistān S.S. Cumhūrīye-ti 'Ulūm Āḳāděmīsi Neșrīyāt Evi, 1941, 1947, 1958). See also Sergi Cikia, "Gürcistan Vilâyeti Mufassal Defteri,” tr. Galip Adıyok, in Bizim Ahiska, vol. Iv, no. 9 (Kış 2008), pp. 32-5, available at http://www.ahiska.org.tr/wp_pdf/sayig/parcali/34_Sayig.pdf. (This is a Turkish translation of a paper given by Dzikiia at a conference in Moscow in 1960, with a new introduction by Yunus Zeyrek.).

7 Encyclopaedia of Islam, First Edition (1813-1936), ed. M. Th. Houtsma, T.W. Arnold, R. Basset and R. Hartmann (Leiden: Brill, 1987), vol. IV, pp. 767-76, s.v. "Tīmār" (Jean Deny).

8 Fekete, Lajos, Az Esztergomi Sandzsák 157o: évi adóösszeirása [The 1570 Tax Census of the Sancak of Esztergom] (Budapest, 1943).

9 For the story, see the introduction to the first issue of Belgeler, I/1 (1964): I-IV. 
Although Fekete's study had some influence, for reasons probably of accessibility and language facility it was not these earlier works but rather Halil İnalcık's publication of the earliest surviving such register, from the sancak of Arvanid (1431), that was most cited as an early model of research. ${ }^{10}$ Inalcık's presentation included a transcription of the text in Romanized characters (and typed Arabic characters for many personal and place names), photographs of selected pages of the original, and indexes of personal and place names (though without identification). The nature of this defter as a record of timar grants, as well as its early date, led İnalcık, in his introduction, to emphasize the register's reflection of Ottoman state processes and categories, not neglecting the taxes collected from the peasant cultivators, but the data itself was not analyzed.

Following İnalcık's lead, subsequent research and publications focused on text editions, and on studies of state administrative procedures and the sancak. This seemed natural enough, since each register typically was devoted to a single sancak, the basic Ottoman provincial administrative unit."1 Dozens of studies of Ottoman sancaks appeared over the next four decades, including numerous additional textual publications of registers. Entire fields of study took shape, such as Ottoman topographical and demographic history, based largely on these materials. Regional economies were described from the quantification of agrarian production and taxation. Administrative and bureaucratic processes were reconstructed. Among many outstanding publications we might point to M. Tayyib Gökbilgin's Edirne ve Paşa Livası as a much cited early standard in which the value of the material overcame its somewhat muddled presentation, and Feridun Emecen's XVI. Asırda Manisa Kazası as a late model, for the depth of insight enabled by this work. ${ }^{12}$ Ottoman regulations (kanuns) were analyzed to describe the structure of the timar, ${ }^{13}$ and the processes and methods used by Ottoman officials in the cadastral surveys and in bestowing the sancak revenues as timar and zeamet grants. ${ }^{14}$

10 İnalcık, Halil, Hicrî 835 Tarihli Sûret-i Defter-i Sancak-i Arvanid (Ankara: Türk Tarih Kurumu, 1954).

11 Dávid, Géza, "The sancak as the framework for research on Ottoman regional studies", in Türkische Wirtschafts- und Sozialgeschichte von 1071 bis 1920. Akten des IV. Internationalen Kongressen, 51-58, ed. Hans Georg Majer and Raoul Motika (Wiesbaden: Harrassowitz, 1995).

12 Gökbilgin, M. Tayyib, Edirne ve Paşa Livası (İstanbul: Üçler, 1952); Emecen, Feridun, XVI. Asırda Manisa Kazası (Ankara: Türk Tarih Kurumu 1989).

13 Beldiceanu, Nicoară, Le timar dans l'état ottoman (début XIV -début XVI ${ }^{e}$ siècle) (Wiesbaden: Otto Harrassowitz, 1980).

14 Beldiceanu-Steinherr, Irène and Nicoara Beldiceanu, "Règlement ottoman concernant le recensemeent (première moitié du Xvie siècle)", Südost-Forschungen, 37 (1978), 1-40; 
In the doing, however, it was not just the defter and the sancak as units of study that were being adopted in research, it was often also the Ottoman administrative mindset. Just as career patterns of Ottoman officials formed an aspect of the research, so Istanbul archival experience became an initiation into the professional guild for a generation of Ottoman historians. It was often said among Ottomanists that our closest friends were the colleagues we met in the archives. Not just personal friendships were formed in archival work, research agendas too were shaped. Relevant new publications and dissertations were circulated and devoured. ${ }^{15}$ Those who worked elsewhere, on literary, religious, and other cultural topics in the manuscript libraries, we often did not know so well. There was shop talk about particular archival classifications and pride in mastery of skills, for instance in reading the siyakat script. Such things were of course natural expressions of a deep love and enthusiasm for our work that is common to all fields. Although the lacunae of our documentary sources were sometimes noticed, researchers forged full speed ahead.

By the mid-1980s, however, some discomfort arose both regarding the supposed certainties that seemed to be routinely invoked in discussions of Ottoman economic and social history, and also the state-centered orientation of the field that informed these results and that was in turn reinforced by them. Heath Lowry's 1986 conference paper came as a first blunt rebuke. Lowry described historians' exaggerated trust in the precise data they compiled, with "incorrect comprehension of [the] strengths and limitations" of the sources, and their naïve methodology, or rather as he put it, the "complete absence of anything resembling a useful methodological approach". The term Lowry coined for the practices he critiqued, "Defterology", incorporated the Ottoman term for the registers and suggested an unselfconscious appropriation of the ideology of the Ottoman state by historians. This latter point was developed by Halil Berktay in a paper published in a special issue of the Journal of Peasant

Gökbilgin, M. Tayyib, “Kanûnî Sultan Süleyman'ın Timar ve Zeamet Tevcihi ile İlgili Fermanları", Tarih Dergisi, 22 (1968), 35-48; Beldiceanu-Steinherr, Irène, "Loi sur la transmission du timar (1536)", Turcica, 11 (1979), 78-102.

15 I should give special mention here to the work of Metin Kunt, who encouraged me when I met him at the annual Middle East Studies Association meeting in Chicago in 1983 . His book, The Sultan's Servants: The Transformation of Ottoman Provincial Government, 1550-1650 (New York: Columbia University Press, 1983), just published, was admired by those working in the archives at the time, and became a stimulus of my own project. Similarly, a UMI microfilms bound copy of Cornell Fleischer's dissertation made the rounds; Fleischer's book, Bureaucrat and Intellectual in the Ottoman Empire: The Historian Mustafa Âli (1541-160o) (Princeton: Princeton University Press, 1986), was still in press. 
Studies (1992) ${ }^{16}$ Asking what was "wrong with Ottoman historical studies", Berktay answered in three words, "nationalism, state-fetishism, documentfetishism,"17 and did not shy from taking on some giants of the field, including İnalcık, Barkan, and even Mehmet Fuat Köprülü, the most prominent historian of the Turkish Republic and a public figure of no small importance.

With its strong implication that scholarly debate was inseparable from selfinterest and, especially, political attitudes, Berktay's edgy essay was situated within the growing "postmodernist" critique of academic practice. ${ }^{18}$ In the circumstances, a reflective stance with regard to contemporary political realities in the field of Ottoman and Turkish studies meant engaging feelings about the Turkish military coup of 12 September 1980 . That is, the critique of defterology challenged historians' underlying commitments to one very common narrative of Ottoman history, the waxing and waning power of the central Ottoman state, and analogously to centralizing states in general and that of the Turkish Republic in particular, which often lay just beneath the surface of much of the published research on Ottoman state records. In this way, while the critics were themselves not really postmodernists, their critique of defterology was a species of the methodological skepticism then sweeping all fields of the humanities in the late 1980 s and 1990s. The discourse analysis of Michel Foucault had raised suspicions about modernist epistemologies, ${ }^{19}$ while post-structuralist methods of deconstruction, associated especially with Hayden White, ${ }^{20}$ JeanFrançois Lyotard, ${ }^{21}$ and Jacques Derrida ${ }^{22}$ and his numerous imitators, ${ }^{23}$ had brought mistrust of all grand narratives as ideological masks. When the Iron Curtain came down across central Europe in 1989 and the Soviet Union broke

16 The papers were also published in book form as New Approaches to State and Peasant in Ottoman History, ed. Halil Berktay and Suraiya Faroqhi (London: Frank Cass, 1992).

17 Berktay, Halil, "The search for the peasant in western and Turkish history/historiography", in New Approaches to State and Peasant, pp. 109-84, quote at p. 109.

18 Jenkins, Keith, The Postmodern History Reader (New York: Routledge, 1997).

19 Foucault, Michel, The Archaeology of Knowledge, tr. A.M. Sheridan Smith (London: Tavistock, 1972).

20 White, Hayden, Metahistory (Baltimore: Johns Hopkins University Press, 1973); White, Hayden, The Content of the Form: Narrative Discourse and Historical Representation (Baltimore: Johns Hopkins University Press, 1987).

21 Lyotard, Jean-François, The Postmodern Condition: a Report on Knowledge, tr. Geoff Bennington and Brian Massumi (Minneapolis: University of Minnesota Press, 1984).

22 Derrida, Jacques, Of Grammatology, tr. G Chakravorty Spivak (Baltimore: Johns Hopkins University Press, 1976).

23 See the discussion of Christopher Norris, Deconstruction and the 'Unfinished Project of Modernity' (New York: Routledge, 2000), pp. 6-24. 
apart two years later, no field of the humanities was left unmoved, as the grand narratives of the preceding forty years, modernization theory and Marxism, came crashing down as well.

To be sure, in the immediate aftermath of the cataclysmic events of 19891991 it seemed that just as the West had won the cold war, so modernization theory was vindicated in the academy. Marxism seemed thoroughly discredited by failed revolution and by the devastation so apparent in the post-Socialist societies of Eastern Europe and the former Soviet Union. Modernization theory enjoyed a triumphant revival, nowhere better expressed than in Francis Fukuyama's celebrated 1989 essay, "The End of History?"24 But the revival was brief. Modernization theory saw history as a natural progression from traditional towards advanced societies, where humanity would reach fulfilment in liberal, democratic institutions characterized by individualism and secular, scientific attitudes. It did not predict the resiliency of religious identities, and did not foresee the decade of stagnation in Japan, the debt crises in Europe, the American housing- and financial-market collapse after 2006, or the appearance of anti-democratic liberalism. When religion, wars, genocide, and gross disparities of wealth did not disappear in the bright new dawning of liberal democracy of the 1990s, the gig was up for modernization theory.

The main popular rival of modernization theory after 1991, Samuel Huntington's "Clash of Civilizations, ${ }^{25}$ was viewed with distaste among academic historians in general and historians of the Islamic societies in particular. Neither its title nor its sweeping generalizations, such as "Conflict along the fault line between Western and Islamic Civilizations has been going on for 1,30o years," 26 were especially new or insightful, having appeared most recently in a Bernard Lewis essay from the time of the first Gulf War, which itself was a rewarmed version of Lewis's work of decades before. ${ }^{27}$ These platitudes forced history into the mold of an ideological formulation that threatened to become a selffulfilling prophesy. Ottoman historians pursued new projects often in the form of history from below, influenced both by the Annales school and even more

24 Fukuyama, Francis, “The End of History?", National Interest (Summer 1989), 3-18; Fukuyama developed the argument in a book, The End of History and the Last Man (New York: Free Press, 1992).

25 Huntington, Samuel P., "The clash of civilizations?", Foreign Affairs 72/3 (Summer 1993), $22-49$.

26 Huntington, “The clash of civilizations?", p. 31.

27 Lewis, Bernard, "The roots of Muslim rage", Atlantic Monthly (September 1990), 24-8. The earlier version appears in a set of lectures Lewis delivered at Indiana University in 1963: Lewis, Bernard, The Middle East and the West (Bloomington, Ind.: Indiana University Press, 1964). 
the Subaltern group. Among them were studies of migrants, ${ }^{28}$ spies, smugglers, and renegades, ${ }^{29}$ slaves and human trafficking, ${ }^{30}$ missionaries and converts, ${ }^{31}$ physicians, ${ }^{32}$ scientists, ${ }^{33}$ merchants, ${ }^{34}$ rebels, ${ }^{35}$ and terrorists, ${ }^{36}$ and others. This research doubled as Ottomanist contributions to a full-bored debunking of the Huntington thesis, documenting a long record of complex, blurred identities in the Ottoman empire that gave the lie to simplistic notions of religious and civilizational loyalty as a means of explaining very much about human history.

Those of us who had worked on timars found ourselves caught in the general disorientation after 1991. This was not everywhere the same and not immediate, of course. One factor in historical research is that the past becomes interesting on its own account, mostly because it is different than our own times. The power of human curiosity should not be underestimated, as many

28 Kasaba, Reşat, A Moveable Empire: Ottoman Nomads, Migrants, and Refugees (Seattle and London: University of Washington Press, 2009).

29 Blumi, Isa, "Thwarting the Ottoman empire: smuggling through the empire's new frontiers in Yemen and Albania, 1878-1910", International Journal of Turkish Studies 9/1-2 (Summer 2003), 255-74; Dávid, Géza and Pál Fodor, "Ottoman spy reports from Hungary", in Turcica et Islamica: Studi in Memoria di Aldo Gallotta, ed. Uggo Marazzi (Naples: Università degli studi di Napoli “L'Orientale”, 2003), vol. I, pp. 121-31; Zarinebaf, Fariba, "Rebels and renegades on Ottoman-Iranian borderlands: porous frontiers and hybrid identities", in Iran Facing Others: Identity Boundaries in a Historical Perspective, ed. Abbas Amanat and Farzin Vejdani (New York: Palgrave Macmillan, 2012), pp. 79-97.

30 Dávid, Géza and Pál Fodor (eds.), Ransom Slavery along the Ottoman Borders (Early Fifteenth-Early Eighteenth Centuries) (Leiden and Boston: Brill, 2007); Toledano, Ehud R., Slavery and Abolition in the Ottoman Middle East (Seattle and London: University of Washington Press, 1998).

31 Minkov, Anton, Conversion to Islam in the Balkans: Kisve Bahası and Ottoman Social Life, 1670-1730 (Leiden and Boston: Brill, 2004); Makdisi, Ussama, Artillery of Heaven: American Missionaries and the Failed Conversion of the Middle East (Ithaca, N.Y.: Cornell University Press, 2009).

32 Shefer-Mossensohn, Miri, Ottoman Medicine: Healing and Medical Institutions 1500-1700 (Albany, N.Y.: State University of New York Press, 2009).

33 Ben-Zaken, Avner, Cross-Cultural Scientific Exchanges in the Eastern Mediterranean, 1560-166o (Baltimore, Md.: Johns Hopkins University Press, 2010).

34 Goffman, Daniel, The Ottoman Empire and Early Modern Europe (Cambridge: Cambridge University Press, 2002); Hanna, Nelly, Making Big Money in 16oo: The Life and Times of Isma'il Abu Taqiyya, Egyptian Merchant (Syracuse, N.Y.: Syracuse University Press, 1998).

35 See the collection of papers on mutinies in International Journal of Turkish Studies, 8/1-2 (Spring 2002).

36 Khuri-Makdisi, Ilham, The Eastern Mediterranean and the Making of Global Radicalism, 1860-1914 (Berkeley and Los Angeles: University of California Press, 2010). 
readers will affirm, and is indeed crucial in motivating completion of research agendas once they are begun. Regarding their 2005 article, ${ }^{37}$ for example, Géza Dávid told me that he and co-author Pál Fodor "were simply eager to know what happened to the timar system". And in the case of Hungary, where the University of Budapest had established the first chair in Turkish studies anywhere in the world, Ottoman history began and continued as an aspect of a national history in a way that was not the case outside the former empire's borders. Beyond those borders, as new research climatic conditions took hold the study of timars languished. Partly, institutional history seemed less urgent, but there were deeper issues. Though not always obvious, timar studies had followed cold war patterns and modernization theory, whose premise required that the old empires, including the Ottoman, were necessarily corrupt, decadent, and incapable of modernizing. Although I and other colleagues working in the defters in the 1980 os were not proponents of modernization theory, we were ironically dependent on it, in that our concern was to defend the Ottoman empire against this premise. We presented a precociously modern Ottoman land regime that seems suspiciously Weberian — highly rational, regulated by principles of justice embodied in the kanun, and implemented by conscientious officials who were answerable to the divan and vulnerable to complaints and petitions of the villagers. To the extent that defense of Ottoman history coincided with defense of Turkish history, our position was exposed by the military coup of 12 September 1980 ; to the extent that it was invested in grand narratives, it collapsed altogether by the mid-199os.

Not that the strength and value of the research we had done and the studies that came out of it were at all diminished, but they seemed inadequate in many respects. We had been driven into a defense of the benevolent character of Ottoman rule by our own circumstances, among them our warm personal experiences of living in Turkey and, in the United States, the bleakly anti-Islamic and anti-Turkish bigotry of public rhetoric after the 1974 oil embargo, the Cyprus war, and the Iranian revolution. Yet while these motivations were probably not fully articulated in the defterology debate, it is still true that in retrospect our closely focused descriptions of Ottoman institutions seem too state-centered, and too narrowly Turkish. They emphasized the central Ottoman 'system', and understated the degree of regional diversity and local adaptations. They insisted on the exceptionalism of the Ottoman case, avoided the European vocabulary of feudalism, and downplayed the

Dávid, Géza and Pál Fodor, "Changes in the structure and strength of the Timariot army from the early sixteenth to the end of the seventeenth century", Eurasian Studies $4 / 2$ (2005), $157-88$. 
complicating role of personal relationships and patronage in Ottoman practices. Our state-centered research, linked to modernization theory in spite of ourselves, made it a cold-war artifact. It seems unsurprising, therefore, that in years after the Iron Curtain was torn down and the Soviet Union broke apart, interest in the Ottoman land regime lessened.

\section{Timars and the Feudalism Debate}

If the preceding might be a reasonably acceptable explanation (and it might not be) of why the field lost interest in timars by the mid-199os, it does not go deep enough. It does not explain what got us interested in timars in the first place. Indeed the cold war had more or less recast an earlier debate, which was about feudalism and land reform. The cold war further politicized and polarized this earlier debate, as American and Soviet and East European scholars weighed in, ${ }^{38}$ and put it in new terms. As scholarship and public interest are always closely related, so too the Turkish Historical Society's project to publish the Ottoman defters beginning in 1947 did not occur in a scientific vacuum but rather fit a context shaped by current events.

The demand for land reform in Turkey was an expression of the Europewide movement to dismantle hereditary privilege, and with it traditional landholding patterns that gave disproportionate power to the wealthy few. That a fundamental motivation of historians working on the Ottoman timar institution was to provide historical background for this contemporary movement can be clearly seen in Halil İnalcık's article "Land problems in Turkish history," which traced the history of the timar institution within the evolution of agrarian relations. ${ }^{39}$ The urgency of the issue was hinted at in an addendum that updated the figures for the amount of land distributed between August 1953, when the article was finished, and the end of 1954, when it went to press. Resistance to land reform was substantial, in Turkey as elsewhere. A decade later, estimates reported that less than ten percent of the farmers still owned half the land, while two-thirds of the farmers in Turkey combined to own less than 20 percent of the land. ${ }^{40}$ Resulting frustration at the slow progress of reform was a contributing factor in the rise of radical revolutionary movements in Turkey by the late 1960 s.

38 Abels, Richard, "The historiography of a construct: 'feudalism' and the medieval historian", History Compass 7 (2009), 1008-1031, at pp. 1012-13.

39 İnalcık, Halil, "Land problems in Turkish history", Moslem World 45 (1955), 221-8.

40 Aktan, Reşat, "Problems of land reform in Turkey", Middle East Journal 20 (1966), 317-34. 
The feudalism debate was the scholarly dimension of this public movement and grew up alongside it during the preceding hundred years. Thus did Jean Deny's entry on the timar in the first Encyclopaedia of Islam (1934) define the timar institution in feudal terms, comparing timars to "western fiefs". In the academic discussion, two sides emerged. One group defined feudalism as a political regime in which a landed estate was held as fief, by a vassal from a lord in exchange for certain obligations and for the purpose of supporting a cavalry army. ${ }^{41}$ For these scholars, feudalism was primarily a system of military administration; social and economic relations and institutions certainly resulted from this, but these were of secondary relevance. The other group defined feudalism as a means of organizing the labor of peasant cultivators for the purpose of appropriating agrarian production. For these scholars, feudalism was primarily a social system; the obligations of those who owned and exercised power over the land were incidental to the material life of village society. Research tended to be divided along these lines, with the first group interested in legal structures and administrative and political processes, and the second group interested in agricultural production and a holistic view of peasant society.

Although the discussion arose in Europe, among both groups there was great interest in other regions because it was evident that broadly similar systems occurred across Afro-Eurasia at the same time. European historians tended to see feudalism as an element of the unique circumstances from which Western civilization emerged out of the ruins of the Roman order. The first group, using a narrowly political and legal approach, who during the cold war generally worked within modernization theory, called for comparative studies out of a desire to know how other societies modernized or (just as often in their interpretations) why they failed to do so. For these historians it was in Japanese historiography more than in Ottoman that the European feudal model found the most enthusiastic embrace. ${ }^{42}$ The presence of strong central authority made the Ottoman empire seem fundamentally different. Of the second group, the scholars using a broader, social-order approach, Marc Bloch provides an outstanding example. ${ }^{43}$ Since feudalism originated in the period when the Roman social equilibrium was upset by the Germanic invasions and

\footnotetext{
41 Stephenson, Carl, Mediaeval Feudalism (Ithaca, N.Y.: Cornell University Press, 1942).

42 Compare Mass, Jeffrey P., "The early Bakufu and feudalism", in Court and Bakufu in Japan: Essays in Kamakura History, ed. Jeffrey P. Mass (New Haven and London: Yale University Press, 1982), pp. 123-42, with Totman, Conrad, "English language studies of Medieval Japan: an assessment”, Journal of Asian Studies 38 (1979), 544-51. See also Duus, Peter, Feudalism in Japan (New York: Alfred A. Knopf, 1969; second ed. 1976).

43 Bloch, Marc, La sociétéfeodale, 2 vols. (Paris: Albin Michel, 1939-1940).
} 
Islamic conquests, Bloch thought it a legitimate question whether similar circumstances elsewhere had perhaps led to the creation of social structures that "sufficiently resembled that of our Western feudalism to justify us in applying the term 'feudal' to them as well". ${ }^{44}$ During the cold war it was Marxist historians who showed great interest in studying the social structures of agrarian societies worldwide for general patterns of historical development amid regional particularities. Their debates revolved around the usefulness of the Marxist, and ultimately Orientalist, concepts of an "Asiatic mode of production" and "Oriental Despotism" as compared with European feudalism. ${ }^{45}$

Certain aspects of the debate took on their own life in Ottoman historiography. One of these, the origins of the timar, merits some attention because of its importance for orientalism and modernization theory. In his Encyclopaedia of Islam entry, Deny argued from the etymology of the term that the timar derived from Byzantine rather than Islamic origins. Though timar was a Persian term, Deny wrote, in Persian it was not used in a military sense; it did, however, "echo" the Greek pronoia, "care, anxiety, pains, dressing", in meaning. ${ }^{46}$ For Deny, this "semantic evolution" of the term timar, and the striking obligation of naval service for both Byzantine and Ottoman soldiers, suggested that "the Turks imitated or rather preserved the Byzantine institution which they found in existence". ${ }^{47}$ It was a sensitive point. Ottoman unoriginality was an axiom of orientalist scholarship, which treated the Ottoman period as a long, dull epilogue to medieval Arab and Persian greatness, and the corollary was to attribute whatever was interesting in Ottoman society and culture to Christian origins, to Christian converts and Christian institutional models.

Moreover in Deny's challenge of two scholar-diplomats of the nineteenth century, François Alphonse Belin (1817-77), and Paul Andreas von Tischendorf $(1847-1914),{ }^{48}$ it is perceptible that the discussion of the origins of the timar might also be a kind of proxy for a debate about the degree to which the

44 Bloch, Marc, Feudal Society, tr. L.A. Manyon (Chicago: University of Chicago Press, 1961), vol I, pp. xvi-xx.

Dunn, Stephen P., The Fall and Rise of the Asiatic Mode of Production (London: Routledge and Kegan Paul, 1982). On the Orientalist origins, see Ali, M. Athar, "The Mughal polity-a critique of revisionist approaches", Modern Asian Studies 27 (1993), 699-710.

The classic work on pronoia is Ostrogorsky, George, Pour l'histoire de la féodalité byzantine (Brussels: Institut de Philogie et d'Histoire Orientales et Slaves; Editions de Byzantion, 1954). See also below.

47 Deny, "Timar", pp. 767-8.

48 Belin, François Alphonse, Du régime des fiefs militaires dans l'islamisme et principalement en Turquie (Paris: Imprimerie nationale, 1870), von Tischendorf, Paul Andreas, Das Lehnwesen in den moslemischen Staaten insbesondere im osmanischen Reich (Leipzig: Giesecke and Devrient, 1872). 
Ottoman empire really lay within "civilized" society by European terms. Belin drew Deny's praise as "the only man who has so far seriously studied the Turkish timar", while Tischendorf he dismissed as "simply a version of Belin's works with a few additions". Indeed the two books, the first European scholarship devoted to Ottoman feudalism, are similar and have identical titles, Belin's in French and Tischendorf's in German. Both established the Islamic genealogy of the timar in the ikta institution of the Seljuk and earlier Islamic empires. There were tellingly different emphases, however. Tischendorf, who dedicated his book to his father, theologian Constantin von Tischendorf, discoverer of the Codex Sinaiticus ${ }^{49}$ was primarily interested in military power. He ended with the speculation "whether the ancient Oriental despotism can be reconciled with the principles of modernity, or whether the Crescent, which even now is enthroned upon Aya Sofya, Justinian's glorious dome, must again give way to the Cross of Christ". Belin, on the other hand, the French consul general in Istanbul, ${ }^{50}$ plainly set his study in the context of contemporary discussions of feudal tenure and concluded that the Ottoman regime was structurally distinct. Belin quoted a passage from the French translation of Ahmet Cevdet Paşa's Ottoman history, that although European feudalism resembled in some ways the Ottoman institutions, the Ottoman royal diploma (the berat) gave access only to the revenue of the land and only for a limited term, allowing no claim of sovereignty over the land or its peasant cultivators. ${ }^{51}$

Responding to Deny, the Turkish medievalist M. Fuat Köprülü steered the origins debate in a different direction, arguing that the antecedents of the $t i$ mar lay in the Seljuk and beylik periods. ${ }^{52}$ The Second World War interrupted the origins debate and, with no simple resolution possible, it became a less significant feature of research in the cold war era.

Rather, during the cold war, European and American scholarship concentrated on assessing the capacity of former Ottoman societies to modernize, and the essential Western vs. Islamic bifurcation of orientalism became a dichotomy of modern vs. traditional societies in modernization theory. ${ }^{53}$

49 And his brother Johannes was a jurist and Senate President in the German parliament. See Friedman, Isaiah, Germany, Turkey, Zionism 1897-1918 (Oxford: Clarendon Press, 1977).

5o Belin, François Alphonse, "Du régime des fiefs militaires dans l'Islamisme, et principalement en Turquie", Journal Asiatique, 15 (1870), 187-301.

$5^{1}$ Belin, "Du régime des fiefs militaires dans l'Islamisme", pp. 189-9o.

52 Mehmet Fuat Köprülü, “Bizans Müesseselerinin Osmanlı Müesseselerine Te'siri Hakkında Bâzı Mülâhazalar”, Türk Hukuk ve İktisat Tarihi Mecmuası, 1 (1931), 165-313, especially pp. 169-73 and 219-40; Köprülü, "Ortazaman Türk-İslam Feodalizmi”, Belleten, 5 (1941), 319-34.

53 Lockman, Zachary, Contending Visions of the Middle East: The History and Politics of Orientalism, second ed. (Cambridge: Cambridge University Press, 2010), pp. 139-40. 
Marxist historians, many of whom were living in now East Bloc successor states of the former Romanov, Habsburg, Hohenzollern, and Ottoman empires, considered religion irrelevant to the discussion and wrote instead from a theoretical commitment to the historical development, through stages, of all societies. There was general recognition that state control of land set the Ottoman regime apart from European feudalism, but sharp disagreement about what this meant. Marxist scholars saw taxation as the defining characteristic of peasant dependency, and viewed the Ottoman period as conquest by nomadic military bands and thus a step backward in historical development.

My purpose here is not to fully evaluate the research of these decades in these few pages, and that would anyway be an impossible task. The research was arduous, the debates complicated, and even the main approaches I have described above were not monolithic. In a lucid summary of the socialist school published in English near the end of the period, ${ }^{54}$ the Bulgarian scholar Vera Mutafčieva stated that Marxist scholars treated the timar as an aspect of a fuller Ottoman agrarian regime, which included not just timars but also land held in trust (vaklf) and in freehold (mülk), and that they used descriptive not prescriptive evidence. ${ }^{55}$ Yet Western scholars were not uninterested in the study of rural society. Even a cursory look at the work of a couple of prominent scholars disproves Mutafčieva's assertion that Western scholars were interested only in the structure of the timar institution and relied on prescriptive evidence such as law codes and sultanic decrees. True, those who used the narrow definition of feudalism as the political relations of power between knights focused on legal and administrative records, and they made publication of Ottoman kanunnames a strength of western scholarship. Yet Ömer Lütfi Barkan's publications covered not just kanuns, ${ }^{56}$ but price fluctuations, historical demography, ${ }^{57}$ and a wide range of other issues. ${ }^{58}$ Barkan's entry on the timar institution in İslam Ansıklopedisi (1974) shows the breadth

54 Moutafchieva, Vera P., Agrarian Relations in the Ottoman Empire in the 15th and 16 th Centuries (Boulder, Colo.: East European Monographs, 1988).

55 Moutafchieva, Agrarian Relations in the Ottoman Empire, pp. 104-21.

$5^{6}$ Barkan, Ömer Lütfi, XV ve XVI ıncı Asırlarda Osmanlı İmparatorluğu'nda Ziraî Ekonominin Hukukî ve Malî Esasları, 1: Kanunlar (Istanbul: İstanbul Üniversitesi Edebiyat Fakültesi Türkiyat Enstitüsü, 1943).

57 Barkan, Ömer Lütfi, "Essai sur les données statistiques des registres de recensement dans l'empire ottoman aux Xve et XVIe siècles", Journal of the Economic and Social History of the Orient, 1 (1957), 9-36; Barkan, "The price revolution of the sixteenth century: a turning point in the economic history of the Near East", tr. Justin McCarthy, International Journal of Middle East Studies, 6/1 (1975), 3-28.

$5^{8}$ Barkan, Ömer Lütfi, Türkiye'de Toprak Meselesi: Toplu Eserler 1 (Istanbul: Gözlem, 1980). 
of interest in all aspects of Ottoman rural life, ${ }^{59}$ and it already appeared before use of the records of the courts of town magistrates (the kadı sicilleri) revolutionized research on all aspects of Ottoman social life. ${ }^{60}$ Halil İnalcık, whose capacious mind took in virtually all fields of Ottoman history, was fully conversant with the theoretical currents, as was Barkan. ${ }^{61}$ Likewise on the other side, Marxist historians such as Anna Stepanova Tveritinova (1910-1973) did indeed study Ottoman law and publish kanunnames. ${ }^{62}$

\section{Towards a New Research Agenda}

By the mid-1990s the contemporary issues that drove interest in timars in our lifetime had dissipated. Land reform was largely accomplished, by force in Eastern Europe in the decades after 1945 and, though it took time, in Turkey too industrialized agriculture eventually broke the paternalism of the village agas and big landlords. When the Iron Curtain came down and the Soviet Union broke up, the global political frame of research cracked. Publications on timars trickled out over the next few years as research projects already underway were completed, but the loss of interest was precipitous.

Of course I was exaggerating when I wrote, above, that everybody lost interest in timars. That was not really true. Indeed there never seems to have been a time when nobody was working on timars. In the post-cold war years important sources have been made available in research libraries around the world.

59 İslam Ansiklopedisi, İslâm Âlemî Coğrafya, Etnoğrafya ve Biyografya Lügatî, ed. Adnan Adıvar et al. (Istanbul: Millî Eğitim Basimevi, 1940-1988), vol. XıI/1 (1974), pp. 286-333, s.v. "Timar" (Ömer Lütfi Barkan); see also Suraiya Faroqhi's telling summary, in Faroqhi, Suraiya, Approaching Ottoman History: An Introduction to the Sources (Cambridge: Cambridge University Press, 1999), pp. 82-109.

6o Çagatay Uluçay, M. Tayyib Gökbilgin, Halil İnalcık, Halit Ongan, and other scholars had published studies based on these materials, but the historiographical breakthrough came through Ronald C. Jennings's work, appearing in English in three articles in the Journal of the Economic and Social History of the Orient: "Loans and credit in early 17th century Anatolian Kayseri", JESHO, 16/2-3 (December 1973), 168-216; "Women in early 17th century Ottoman judicial records", JESHO, 18/1 (January 1975), 51-114; and "Zimmis (non-Muslims) in early 17th century Ottoman judicial records", JESHO 21/3 (October 1978), 225-93.

61 A relevant example is İnalcık, Halil, "The impact of the Annales School on Ottoman studies and new findings", Review, 1/3-4 (Winter-Spring 1978), 69-96.

62 For references, see Kirillina, Svetlana, "Russian historiographical tradition in oriental studies: the Arab periphery in the Ottoman empire", Turkish Studies Association Bulletin, 22/2 (Fall 1998), 1-12, at p. 12 and note 29 . 
A series of tahrir registers was published by the General Directorate of the Prime Ministry Archives, in clear and readable facsimiles, some with transcription into Roman characters, and indices, in a large-format series with matching bindings. ${ }^{63} \mathrm{~A}$ large number of kanunnames, including many important texts concerning aspects of the timar and agrarian life, were published in a multivolume series by Ahmet Akgündüz. ${ }^{64}$ Research continued to percolate in doctoral institutions and bubble up into dissertations and conference papers. In some publications a problem-oriented research agenda began to replace the source-driven focus, a measure of the growing distance between Ottoman historians and the mindset of the Ottoman scribe. This points to a willingness to move beyond Ottoman exceptionalism, insofar as that exceptionalism coincided with systematized conceptions of the contents of the Ottoman archives. Abstracts available at the Higher Education Council (YÖK) website show that sancak-level studies continued to be a popular thesis topic; many of these have appeared in print. ${ }^{65}$ Although much of this work is still limited to transcriptions of registers with little analysis, at its best this work demonstrates the degree to which research agendas were shifting. Among the best examples might be Muhsin Soyudoğan's, whose paper appears below. His dissertation, directed by Oktay Özel, includes a literature survey more nuanced than what I have been able to do here, and with a better grasp of intellectual developments in the Turkish literature. ${ }^{66}$ Among the others, İbrahim Erdoğdu's stands out, ${ }^{67}$ directed by Özer Ergenç, which is about the transition from timar to iltizam in Harput, as does that of Leyla Aksu Kılıç, directed by Bahaeddin Yediyıldız, which draws out a longer historical chronology of the institution. ${ }^{68}$

Three points emerge from historical discussions and the experience of the past 25 years that bear upon a renewed interest in the Ottoman timar. ${ }^{69}$ One is

63 But others also, for example the recent publication of the very early Aydın register, T. T. oo1/1 M. Numaralı Fatih Mehmed Devri Aydın İli Mufassal Defteri (Metin ve İnceleme), ed. M. Akif Erdoğru and Ömer Biylk (İzmir: Ege Üniversitesi, 2015).

64 Akgündüz, Ahmet, Osmanlı Kanunnâmeleri ve Hukukî Tahlilleri, 9 vols. (Istanbul: Fey Vakfı, 1990-1996), vol. 10 (Istanbul: Osmanlı Araştırmaları Vakfi, 2015).

65 Gürbüz, Adnan, XV-XVI. Yüzyıl Osmanlı Sancak Çalışmaları (Istanbul: Dergah, 2001).

66 Soyudoğan, Muhsin, "Reassessing the Timar System: the Case of Vidin (1455-1693)", unpublished Ph.D. Dissertation, İhsan Doğramacı Bilkent University, 2012, pp. 72-110.

67 Erdoğdu, İbrahim, "Xvır. Yüzyılın İkinci Yarısında Osmanlı Toplumunda Değişim Eğilimleri (Harput Örneği)”, unpublished Ph.D. Dissertation, Ankara University, 2006.

68 Aksu Kılıç, Leyla, “Tarihi Süreç İçinde Tımar Sistemi: Ordu Yöresi (1455-1839)", unpublished Ph.D. Dissertation, Gazi University, 2012.

69 Calás, Marta B. and Linda Smircich, "Past postmodernism? reflections and tentative directions", The Academy of Management Review, 24 (1999), 649-71. 
that, as historians themselves became preoccupied with Lyotard's "incredulity towards metanarratives", their study of the old empires, including the Ottoman, did not diminish but ironically flourished, albeit in significantly different ways. Another is that as historians became more self-conscious about methods of narration, they searched for theoretical means of explaining complexity. And third, historians became more transparent about motivations for study and personal involvement in the objects of research.

First, released from modernization theory, historians stopped obsessing on the decline of empires and began asking rather what made them last for as long as they did. If there is anything left of the interpretation of Ottoman history based on notions of the timar as an institution that grew into its 'classical' essence and then declined, the articles presented below should be the final nails in that coffin. Linda Darling especially highlights the difficulties and alternatives of received wisdom. Building upon her work of the last few years, Professor Darling triangulates the icmal registers of the defterhane, the mühimme registers of the divan, and the nasihatname literature. The constant ups and downs of timar practices, usually related to long-standing Ottoman political and social debates and dilemmas, call into question simplistic periodization schemes. It is to my mind the first effort to use documentary sources to draw a generalized picture of timar practices over the entire empire over a substantial period of time. Such results emphatically demonstrate the importance of avoiding tight conclusions based on limited evidence, either geographically or chronologically. Muhsin Soyudoğan's article offers a theoretical approach with potential for advancing research on the timar institution after modernization theory and its lines of explanation are abandoned.

The collapse of modernization theory spells the end not just of Eurocentrism but of exceptionalism of any kind, in Ottoman studies and all historical research. There is no credible reason that comparison with European trajectories stand at the methodological starting point of world histories. ${ }^{70}$ Nor, precisely, did the Ottoman empire develop outside normal currents of history. To appropriate Ian Tyrrell's wording, exceptionalism is overcome when particular instances, such as the European history of feudalism, or the Ottoman history of timars, are reconceptualized as variations on transnational themes. ${ }^{71}$ If it is correct to see the Ottoman timar functioning as an institutional hinge

70 Chakrabarty, Dipesh, 'Postcoloniality and the artifice of history: who speaks for 'Indian' pasts?", Representations, 37 (1992), 1-26, and the same author's Provincializing Europe (Princeton, N.J.: Princeton University Press, 2000).

71 Tyrrell, Ian, "American exceptionalism in an age of international history", American Historical Review, 96 (October 1991), 1031-55. 
between networks of local agrarian production on the one hand and structures of regional security on the other, then the timar is one version of broadly comparable linkages throughout practically all regions of Afro-Eurasia and the Americas in the agrarian age. ${ }^{72}$ Over time these linkages evolved in accordance with new technologies of exchange and monetization. Identifying the common characteristics of these practices and processes, and distinguishing distinctively Ottoman features from those in other regions, will enable us to describe the Ottoman expression of late agrarian age culture in its larger human context. New research on Ottoman timars must ask broader questions and adopt a wider vision.

An immediate problem is the limited usefulness of our English-language terminology, which was derived from the historiography of European feudalism. I take it as one aim of new research to develop a suitable conceptual vocabulary for the institutional hinges by which the agrarian surplus was appropriated to the security apparatus of early modern states, one having the flexibility required for use of specific regional terminologies. To facilitate this the false, but nonetheless highly charged, European vs. Islamic dichotomies of Erdoğanera Turkey specifically and all Euro-American societies generally must be set aside. Perhaps the place to start is to reopen the timar origins debate along the lines suggested by Colin Imber, who has written of "two types of Ottoman timar", one an adaptation of the Byzantine pronoia and the other of the Seljuk iqta. ${ }^{73}$ The short-term aim would be to bring together the arguments of Deny, Köprülü, and İnalcık by considering the close interrelationships of forms of land tenure and government investiture, throughout the whole region from the Danube to the Tigris and from the Adriatic to the Arabian Seas, roughly from the time of Alexius I Comnenus and Kılıç Arslan I down to that of Murad I Hüdavendigar, Stefan Dušan, and the Muzaffarids. ${ }^{74}$ Clarifying these interrelationships in southwestern Eurasia would be a step towards a desperately

72 For a similar view that takes in especially the specific conditions of widespread rise of the warrior class after the fall of the Tang dynasty, see Barandse, R.J., "The feudal mutation: military and economic transformations of the ethnosphere in the tenth to thirteenth centuries", Journal of World History 14/4 (2003), 503-29; for a rebuttal, see Morillo, Stephen, "A 'feudal mutation'? Conceptual tools and historical patterns in world history", Journal of World History, 14/4 (2003), 531-50.

73 Imber's whole discussion of the institution is excellent. Imber, Colin, The Ottoman Empire, 1300-1650: The Structure of Power (New York: Palgrave Macmillan, 2002), pp. 193-206; quote at p. 196.

74 Kazhdan, Alexander, "Pronoia: the history of a scholarly discussion", Mediterranean Historical Review, 10 (1995), 133-63; Bartusis, Mark C., Land and Privilege in Byzantium: The Institution of Pronoia (Cambridge: Cambridge University Press, 2012), pp. 579-96. 
needed dialogue with historians of the Delhi Sultanate ${ }^{75}$ and, in the long run, towards greater precision in comparative discussions of the Ottoman, Safavid, and Mughal empires. Ottoman historians almost never cite Irfan Habib's comprehensive Agrarian System of Mughal India, ${ }^{76}$ to offer the most obvious example, yet its value for comprehending the fuller context of the timar institution is immense-far greater than that of Marc Bloch, for instance. The reasons for the reticence of historians of the Ottoman empire to venture into these comparative climes are certainly complicated, and this is not the place to go into them. Yet it is perhaps not only due to a cultural preference for European comparisons, or Ottoman exceptionalism, but at least partly due to a keen sense that, dynastic spiritual commitments notwithstanding, when it comes to the structure of their agrarian regimes, the three "gunpowder empires"77 (so known from the subtitle of the third, unfinished, volume of Marshall Hodgson's magisterial work $)^{78}$ cannot be meaningfully isolated from the winds of the European peninsula and Russia, or northern Africa, nor, I add, should they be separated from Ming China. In the historiographies of all these regions debates about the applicability of the conceptual vocabulary of feudalism ran in parallel lanes. ${ }^{79}$

Second, we need theoretical strategies oriented towards explaining complexity. Even the well-known Ottoman defters need to be reread and reimagined as telling bigger stories than what state-focused research had

75 The standard statement is Yadava, B.N.S., Society and Culture in Northern India in the Twelfth Century (Allahabad: Central Book Depot, 1973). See also Jackson, Peter, The Delhi Sultanate: A Political and Military History (Cambridge: Cambridge University Press, 2003).

76 Habib, Irfan, The Agrarian System of Mughal India 1556-1707, Third ed. (New Delhi: Oxford University Press, 2014), esp. pp. 298-341.

77 Two important syntheses are Streusand, Douglas, Islamic Gunpowder Empires: Ottomans, Safavids, Mughals (Boulder, Colo.: Westview, 2010), and Dale, Stephen F., The Muslim Empires of the Ottomans, Safavids, and Mughals (Cambridge: Cambridge University Press, 2010); another effort is D'Souza, Rohan, "Crisis before the fall: some speculations on the decline of the Ottomans, Safavids, and Mughals", Social Scientist 30 (2002), 3-30.

78 Hodgson, Marshall G.S., The Venture of Islam, vol. 3, The Gunpowder Empires and Modern Times (Chicago and London: University of Chicago Press, 1974).

79 For reviews of the literature, see Ostrowski, Donald, "The military land grant along the Muslim-Christian frontier", Russian History 19/1-4 (1992), 327-59; Sharma, R.S., "How feudal was Indian feudalism?", Social Scientist 12/2 Marx Centenary Number 3 (1984), 16-41; Foran, John, "The modes of production approach to seventeenth-century Iran", International Journal of Middle East Studies 20/3 (1988), 345-63; Dirlik, Arif, "Social formations in representations of the past: the case of 'feudalism' in twentieth-century Chinese historiography", Review (Fernand Braudel Center), 19 (1996), 227-67. 
told. ${ }^{80}$ We can take some comfort from the anonymous sixteenth-century Ottoman state official known as Pseudo-Ali Çavuş of Sofia, who in one of the most important Ottoman studies of timars ruefully confessed his own generation's overconfidence in the defters. He wrote,

As for [the term] "Excluded from the register" (hariç ez defter): Most of our predecessors had become convinced that this was an impossibility. By the strength and power of the sultans' sovereignty, the totality of the well-protected domains, all its cities and citadels, the products and persons of its villager and fields, had been repeatedly surveyed. Its borders, territories, and dependencies, its mountains and hills, its White Seas and Black Seas, its latitude and longitude, every island and waystation, each dwelling and warship —every single thing was in those registers. ${ }^{81}$

It is not hard for me to think of cases I encountered in my dissertation research three decades ago whose explanation simply could not be found in the Ottoman defterhane records I was reading. ${ }^{22}$ Disputed timar bestowals, for example, and other such problematic cases from the day books (ruznamçes) strongly suggest that within its bureaucratic casing the timar institution was shaped by personal relationships and other informal operations. The quite frequent voluntary cession of timars by sipahis who after a time acquired another timar, a phenomenon to which Muhsin Soyudoğan's paper here also refers, point to the same conclusion. These cases raise the question of military families, all but ignored in the defters. Other examples too show that many activities and operations referred to in the registers actually occurred outside them, including the auxiliary institutions like the falconers (bazdaran), whose timars were recorded in separate sections of some registers in Anatolia province, the fortress guards, and the timars of scribes. As Linda Darling emphasizes, this means a renewed stress on the diversity of Ottoman society, including Ottoman military society. As Darling points out, despite the exclusivist rhetoric of its theologians and chroniclers the early Ottoman empire granted timars to Christian knights, a fact still not well-enough appreciated. This evidence accords with

8o Emecen, Feridun, "Sosyal Tarih Kaynağı Olarak Osmanlı Tahrir Defterleri", Tarih ve Sosyoloji Semineri, 28-29 Mayıs 199o, İstanbul (Istanbul: İstanbul Üniversitesi Yayınları, 1991), pp. $143-56$.

81 Sertoğlu, Midhat (ed.), Sofyalı Ali Çavuş Kanunnâmesi (Istanbul: Marmara University, 1992), pp. 115-16.

82 On the registry, Afyoncu, Erhan, Osmanlı Teşkilatında Defterhâne-i Âmire (XVI-XVIII. Yüzyıllar) (Ankara: Türk Tarih Kurumu Yayınları, 2014). 
similar confessional and ethnic inclusivism in the elite ranks of other contemporary military hierarchies. ${ }^{83}$

For understanding this complexity, the actor-network approach of John Law has shown promise among post-1989 theoretical frameworks. ${ }^{84}$ Especially, it is useful for analyzing layered, institutionalized practices and enables us to embed regional variety in an evolving Ottoman fiscal model. This is one reason why close study of sancaks beyond Rumeli and Anatolia are especially valuable. ${ }^{85}$ Additionally, we need a better understanding of regional and administrative change over time. New diplomatic studies of state documentation have advanced this immeasurably. ${ }^{86}$ Comparative regional longitudinal studies, such as Muhsin Soyudoğan's paper published below, improve our understanding of the ways timariots were involved in local economies. This means also analyzing how varied were even the centrally devised administrative practices. The kadı sicils would undoubtedly also be useful in this regard; although these

83 Mongol inclusivism is well-known, but it also may have been consciously mimicked elsewhere, as has been suggested to explain Ottoman deportation and resettlement policies; see two essays by Heath Lowry, "From lesser wars to the mightiest war': the Ottoman conquest and transformation of Byzantine urban centers in the fifteenth century,", and "Portrait of a city: the population and topography of Ottoman Selanik (Thessaloniki) in 1478", both reprinted in Lowry, Heath, Studies in Defterology: Ottoman Society in the Fifteenth and Sixteenth Centuries (Istanbul: Isis, 1992), pp. 47-64 and pp. 65-99, respectively. In India, for example, not only did the Mughal elite include Rajputs and other Hindu warriors, but some Hindu divines even received jagirs; see Habib, The Agrarian System of Mughal India 1556-1707, p. 356. For the Delhi Sultanate, see Kumar, Sunil, "The ignored elites:Turks, Mongols, and a Persian secretarial class in the early Delhi Sultanate", Modern Asian Studies, 43/1 (2009), 45-77.

84 Law, John, "Notes on the theory of the actor-network: ordering, strategy and heterogeneity", Systems and Practice, 5/4 (1992), 379-93.

85 Some noteworthy examples are Clayer, Nathalie, "Note sur la survivance du système des timâr dans la région de Shkodër au début du Xx ${ }^{\mathrm{e}}$ siècle", Turcica, 29 (1997), 423-31; Moreau, Odile, "La création de deux régiments de cavalerie timariote bosniaque en 1874", Anatolia Moderna/Yeni Anadolu, 7 (1997), 17-48; and Erdoğru, M. Akif, "Rodos Adasında 1711 Yılında Timarlar ve Timarlılar", Tarih İncemeleri Dergisi, 13 (1998), 25-48.

86 Kołodziejczyk, Dariusz, "The Defter-i Mufassal of Kamaniçe from ca. 1681-an example of a late Ottoman tahrir: reliability, function, principles of publication", Osmanl Araştırmaları 13 (1993), 91-8; Svanidze, M.H., "Ahısha (Çıldır) Eyaleti'nde 'Defter-i Caba-i' (1694-1732) Verilerine Göre Timarların Ylllık Gelirleri”, XII. Türk Tarih Kongresi, Kongreye Sunulan Bildiriler (12-16 Eylül 1994) (Ankara: Türk Tarih Kurumu Basımevi, 1999), vol. III, pp. 861-7; Minkov, Anton, "Ottoman tapu title deeds in the eighteenth and nineteenth centuries: origin, typology and diplomatics", Islamic Law and Society, 7/1 (2000), 65-101; Mete, Zekâi, "Osmanlı Taşrasında Bürokratik Muâmelât: Sancakbeyi Belge ve Defterleri", Osmanlı Araştırmaları, 19 (1999), 181-221. 
are state records (indirectly), they are of a different kind, where the timariot is not the central figure but enters the record alongside other subjects. Timariots need to be seen within military households, and within communities. Linking the study of Ottoman timars to two other bodies of Ottoman historiographical literature might both enlighten understandings of administrative practices and better contextualize the lives of Ottoman cavalry personnel-the literature on local elite households is well-developed, the literature on Ottoman nomadism less so. ${ }^{87}$

The diversity and inconsistency of the records and the evidence and the constantly changing standards calls to mind Susan Reynolds's Fiefs and Vassals. ${ }^{88}$ Though again I have not seen it cited much in our field, in several relevant ways it recalls the complexity encountered in the study of Ottoman timars. In a long and often technical study, Reynolds reviewed the European institutions of vassalage and the fief to analyze the extent to which they are "definable, comprehensible, and helpful to the understanding of medieval history". Reynolds pointed out that the meaning of technical terms was not necessarily stable over time, and that actual practices might vary substantially from place to place, even while the same terms were being used for them. Legally minded medieval scribes labored to standardize the terminology of feudalism, and it was their vocabulary, adopted by historians, that shaped our historiographical models. Here Reynolds built on earlier suggestions of Elizabeth A.R. Brown, who had memorably summarized the "hesitations, contradictions, and inconsistencies" of historians' use of the terms and concepts of feudalism which, however, were yet deemed indispensable for heuristic purposes. ${ }^{89}$ Brown had shown that "eighteenth-century British writers began to accept the concept of a uniform feudal government and to concentrate on the system, the construct, instead of investigating the various social and political relationships found in medieval Europe". ${ }^{90}$ Reynolds's argument about the fundamentally interpersonal nature of European feudal relations drew this out, and also interestingly reminds me of the call put forth by Rifaat Ali Abou-El-Haj decades ago, for an

87 Lindner, Rudi Paul, Nomads and Ottomans in Medieval Anatolia (Bloomington, Ind.: Uralic and Altaic Series, 1983); Kasaba, A Moveable Empire: Ottoman Nomads, Migrants, and Refugees.

88 Reynolds, Susan, Fiefs and Vassals: the Medieval Evidence Reinterpreted (Oxford: Oxford University Press, 1994).

89 Brown, Elizabeth A.R., "The tyranny of a construct: feudalism and historians of medieval Europe", American Historical Review, 79/4 (1974), 1063-88.

9o Brown, "The tyranny of a construct: feudalism and historians of medieval Europe", p. 1064. 
alternative model for understanding Ottoman history using the evolution of elite households. ${ }^{91}$

Reynolds's and Brown's observations strengthen my sense that we need to step back from our commitment to an Ottoman timar "system," and rather return the timar institution to its rightful place in a larger Ottoman fiscal model. It is worth remembering the overlapping, fluid boundaries of the divan chancery and the treasury, especially when it came to the registry office that handled timar affairs. Here I address myself more than anyone; after all, I titled my own dissertation "The Ottoman Timar System and its Transformation." In Ottoman studies at the time we seem to have had systems for everything - the devşirme system, the medrese system, the guild system, the kul system, the millet system, and many others. I lost count of how many systems there were. They emphasized rational procedures and directed, top-down structures in which the Ottoman 'state' created a benevolent order that was always threatened by corruption and social discord. In the timar system we stressed the statedirected management of agrarian extraction by conscientious Ottoman officials. This fiscal model, however, was always inappropriate for some regions, including the Caucasus and the Kurdish and Arab tribal regions of the upper Tigris and Euphrates, and when it proved inadequate for major international wars in the 1580s-159os it had to be abandoned. As we gain respect for the fiscal model that replaced it, centered on revenue contracting and capital accumulation in trusts (vaklf), ${ }^{92}$ we see the need to better understand the place of the timar army within it. Özer Ergenç's work on the "free" (serbest) benefice is a good example of the integrated approach to timars within the Ottoman fiscal regime. ${ }^{93}$

Third, a greater level of self-consciousness ought to inform this new research. As a younger scholar I was not fully conscious of my motivations for research, yet it does not seem surprising to me now that I, the son of an air force officer who made a career in managing logistics and supply, would study military administration. Of course scholars all bring their biographies to their work, and we are complicated people. I had come of age in Adana during the

91 Abou-El-Haj, Rifaat Ali, "The Ottoman vezir and paşa households 1683-1703: a preliminary report", Journal of the American Oriental Society, 94/4 (1974), 438-447.

92 Salzmann, Ariel, "An ancien régime revisited: 'privatization' and political economy in the eighteenth-century Ottoman empire”, Politics and Society, 21/4 (1993), 393-423.

93 Ergenç, Özer, "Osmanlı'da 'Serbest Dirlik' Uygulanmasının Boyutları ve Bunun Mâlîİktisadî Faaliyetlerin Düzenlenmesindeki Yeri”, in Birinci İktisat Tarihi Kongresi Tebliğler, ed. Rahmi Deniz Özbay, Fahri Solak, Yaşar Bülbül and Gülfettin Çelik (Istanbul, İstanbul Ticaret Odası, Ekonomik ve Sosyal Tarih Yayınları, 2010), vol. I, pp. 591-7. 
years of the Cyprus conflict, when my father was stationed at Incirlik Air Force Base, but Ottoman historians come into the field from various routes (in the United States one significant route for my generation led through the Peace Corps), and I do not mean to suggest that all routes are as obvious as my own seems to me now.

The circumstances of the 1980 s and the critique of defterology brought a certain healthy self-reflection into a field not accustomed to transparency about our biographies or the sources of our theoretical commitments. I can see now that as a doctoral candidate at Indiana University, working under the tutelage of Gustav Bayerle we both, teacher and student, were cold war people, albeit in very different ways, he as a refugee of one superpower and I as a tagalong dependent of another. Professor Bayerle had participated in the 1956 Hungarian Revolution and fled across the border to Austria when the Soviet army put down that revolt. Abandoned to his fate like the other refugees, Gustav left for New York to continue his studies in Finno-Ugrian philology. He gave that up, however, and became a student of Tibor Halasi-Kun at Columbia University, studying Ottoman rule in Hungary which, he once told me, seemed a kind of distant analogy to his country's recent past. In his Ottoman Tributes in Hungary Professor Bayerle published the detailed (mufassal) register of Novigrad from the cadastral survey of 1570 and the summary (icmal) register of 1579 from the same sancak, with a gazetteer, indices, a glossary, and an introduction. ${ }^{94}$ It represented an extension, to the sixteenth century, of the defter research agenda in which his own teacher played a formative role.

My own work in this new agenda for timar studies comes directly out of my relationship with Professor Bayerle. I and Géza Dávid have set for ourselves the task of a joint project to publish Ayn Ali's Kavanin-i Al-i Osman (16og). We met in the Başbakanlık Arşivi in 1985, but our professional cooperation is also a mature flowering of seeds planted just as the cold war was ending. Professor Bayerle and György Hazai initiated a collaborative research program, funded by IREX, the International Research and Exchanges Board, with the aim of publishing Ottoman sources. The first meeting of this group of Hungarian and American scholars was held in Bloomington, Indiana in August 1988, and the second in Hungary in June, 1989, at just the moment when the fences along the border with Austria were being cut. I arrived in Budapest with the other Americans three days after the remains of Imre Nagy were reburied in a public ceremony. Our group met once more, in Boston, and a number of scholarly studies can be traced to our efforts. In my case my friendship with Géza, as well as Pál Fodor and János Hóvári, was furthered by professional meetings, 
by encounters in the archives in Turkey, and by the Calvin College semester in Hungary program, which took me to Budapest several times over the last 20 years. After Géza contacted me about Ayn Ali, our work was immensely aided by his 2014 stay in Grand Rapids, Michigan, on a Fulbright fellowship with Calvin College as the host institution, and by my return visit to Budapest in the fall of 2015 .

Just as in our times the timar has been studied for its relevance to contemporary issues, it has always been so. It was no different for Ayn Ali himself, who studied the timar as an active institution and used his treatise to advocate for certain policy recommendations. Ayn Ali also wrote a treatise on finance and protocol, which is frequently found copied alongside his Kavanin in manuscripts, besides a short work on astrology; but the Kavanin-i Al-i Osman seems to have been the most successful. More than 50 manuscript copies survive, a large number for such a non-religious, thematic essay. The Kavanin contains lists of Ottoman provinces, an explanation of basic technical terms, and an analysis of how timars were bestowed. In the first recension of the text, attested by a single manuscript that Barkan first noticed, ${ }^{95}$ Ayn Ali's recommendations emphasized the need for proper record keeping, particularly of the musters (yoklama) on campaign. These recommendations were expanded in the version of the text that became famous, the one dedicated to Grand Vezir Kuyucu Murad Paşa, who had defeated the Celali rebels. In this version Ayn Ali emphasized maintaining the strength of the timar army not just by attention to the musters but also by preserving the unity of the core revenues of each timar, the kilıç. To support the point he created lists of the numbers of timar estates, their revenues, and the number of soldiers each province should produce. The data in these lists were especially valued, and were copied by numerous later authors including Paul Rycault and Luigi Marsigli, as well as Koçi Bey, Katib Çelebi, Evliya Çelebi, and Hezarfen Hüseyin. Similarly, although the Istanbul publication of the Kavanin by Şinasi was printed with no introduction by the editor, ${ }^{96}$ yet since this was the time when the mecelle was promulgated it is not difficult to surmise that it fit discussions of kanun and sharia in Ottoman legal reforms. Nor is it likely that Şinasi was unaware of the continent-wide debates of feudal tenure referred to above.

95 He described this manuscript in the "Timar" article in İslam Ansıklopedisi, 12/1 (1974), p. 319 .

96 Şinasi published the text in Tasfir-i Evkar, together with another work by Ayn Ali, the Risale-i Vazife-horan, and also with Katib Çelebi's Düstûrül-amel li-sslâhi'l-halel, in Kavanin Risalesi (Istanbul, 1863/64). 
A new edition of this important text is badly needed for our own times. An English translation, which has never been done, would make the Kavanin accessible for a global audience of scholars. Şinasi's edition is still available in a republication, ${ }^{97}$ but it unnecessarily confuses the reader and misrepresents the text in its visual presentation of the tables. Of the other published editions, Tischendorf's is to be preferred despite Deny's negative judgment, since where Belin gave only a partial French translation, Tischendorf did us the favor of a full German translation, comparing six manuscripts, even if he did mostly follow the Turkish text. Yet neither of the two is easy to find today, and their accompanying studies are inadequate by now. The text needs to be closely examined to clarify issues raised by discrepancies in the lists, and to analyze Ayn Ali's interpretations based on what we have learned of the timar institution in the past century of study.

Especially, from my point of view, in Ayn Ali's definitions of terms we can see the extent to which local practice and usage varied empire-wide, and we can observe his argument for a standardization of practice across the empire which did not in fact exist. Thus might the work of this eminent Ottoman state servant now be put to the service of a non-state history of the timar institution.

97 Under the title Kavânîn-i Âl-i Osman der Hülâsa-i Mezâmin-i Defter-i Dîvân, but including all three works, with a new introduction by M. Tayyib Gökbilgin (Istanbul: Enderun Kitabevi, 1980). 